\title{
The Learning Continuum of Ecological Aspect Based on Complexity Level According to Elementary School Teacher's Opinion
}

\author{
Hani' Faridah ${ }^{1, *}$ Bambang Subali ${ }^{2}$ \\ ${ }^{1}$ Biology Education, Postgraduate Program, Yogyakarta State University, Jl. Colombo No. 1, Karang Malang, \\ Yogyakarta, 55281, Indonesia \\ ${ }^{2}$ Biology Education, Faculty of Mathematics and Natural Science, Yogyakarta State University, Jl. Colombo No. 1, \\ Karang Malang, Yogyakarta, 55281, Indonesia \\ *Corresponding author. Email: hani.faridah331@gmail.com
}

\begin{abstract}
This research is a descriptive research using the survey method. This research aims to collect elementary school teacher's opinion about the learning continuum of ecological aspects based on the level of complexity. The research data is conducted by means of a questionnaire. The research use the hypothetical population and convenience sampling. Respondents in this research consist of 156 teachersI elementary school teachers from Yogyakarta and Bantul regency. The results data are processed with statistical descriptive technique to find the data modus. Based on the results assessment of the complexity level of ecological aspect according to elementary school teacher's opinion, the learning continuum of ecological aspects can be taught at V and VI of elementary school grade, for elementary school grade ecology material with complexity level 2 (simple) and level 3 (rather complex) can be given, while for the secondary school grade, it can be taught taught at VII and VIII of junior high school grade, and for this grade ecology material can be given with complexity level 3 (rather complex) and level 4 (complex).
\end{abstract}

Keywords: learning, continuum, ecology, complexity.

\section{INTRODUCTION}

Learning continuum (LC) is a logical and systematic sequence that shows the vertical connection of material from an aspect of science in learning [1]. It is a way to teach science that has many aspects and has a broad and complex material coverage to make it easier to learn because it is arranged continuously for basic education to the next level of education [2]. LC ranging from simple to complex will be able to describe each phase of student development. It can make it easier for teachers to plan learning activities, because with the formulation of detailed teaching material indicators, the teacher will be able to present material to students in a complete and orderly manner [3]. Standards that pay attention to the essence of LC in developing a curriculum are also needed [4].

The curriculum is one aspect that is very important because it is a guide in the implementation of the learning process at various types and levels of education [5]. If the curriculum is developed by paying attention to the suitability of teaching material at each level of education, it will be able to make learning more effective [6]. The competencies set out in the curriculum have a level of competence that students must achieve gradually, so in the curriculum preparation, they should pay attention to the suitability between the teaching materials used and the age and development of students [7]. Besides, the curriculum used should ideally imply gradation of students' competency levels and the preparation of teaching materials tailored to the stages of development of students at each level of education. In other words, the formulation of the scope of teaching materials should be adjusted to the development of students so that scientific concepts are parallel to the knowledge that students have obtained and are appropriate at every level of education [3].

One of the sustainable sciences taught from elementary to secondary education is Natural Science or Biology. Biology is a science that has a very broad scope in studying the science of living things and their interactions with the surrounding environment [8]. One of the aspects in Biology is Ecology. It has quite a lot of material coverage so it needs to be taught gradually and 
continuously. Thus, the mapping of ecological aspects as teaching materials for primary to secondary education levels based on the level of complexity is expected to make it easier for students to learn.

Presentation of competency levels and characteristics of pedagogical materials that are still overlapping in elementary and high schools' curriculum has become a problem [3]. Based on previous research, these competency level still adhere to the opinions from some groups of respondents and tends to follow the presentation in the curriculum [9],[10]. From this background, the researcher was interested in examining the personal opinions of elementary science teachers about the ecological aspect's LC based on the level of complexity without referring to the applicable curriculum. The purpose of this study was to collect the opinions of elementary school (ES) teachers about the LC of ecological aspects based on the level of complexity. The results of this study are expected to be a useful material to consider in curriculum development, especially for the LC of ecological aspects for elementary to secondary education levels.

\section{RESEARCH METHOD}

This research is a descriptive research using survey method. The survey was conducted by distributing questionnaires to collect the opinion of elementary school teachers about the learning continuum of ecological aspects based on the level of complexity. This research was conducted from February to May 2020. The population of this study followed a hypothetical population rule and the sample was a conventional sample according to Daniel (1989:2-6) [11]. The total sample in this study amounted to 156 respondents who were representatives of a hypothetical population who had appropriate characteristics. The population in this study were all elementary school teachers in Yogyakarta and Bantul regency, while the sample used in this study were teachers in grades I-VI from 12 elementary schools in Yogyakarta and 14 elementary schools in Bantul Regency. The total respondents were 156 teachers.

From the results of filling out the questionnaire, data recapitulation and data processing were carried out. The analysis of research data is descriptive statistical analysis. Data processing is done to find the greatest percentage of frequency (modus) of all data that has been collected, to see the learning continuum of ecological aspects based on the level of complexity according to the opinion of elementary school teachers.

\section{RESULTS AND DISCUSSION}

Based on Piaget's theory, the stages of student development consist of four stages, namely sensory motor (ages 0-2 years), pre-operational (ages 2-7 years), concrete operational (ages 7-11 years), and formal operational (ages 11 years old and above) [12],[13]. When viewed from this stage of development, elementary school students who are children aged 7-11 are at the concrete operational stage [14],[15]. At a basic level in education, teaching materials in ES should be adjusted properly so that they can build basic concepts for learning at the next level [16],[17]. Therefore, the opinions of elementary school teachers are very much needed in the development of LC because they are educators of the early-learning-stage students and understand how ES learners develop in real conditions and how deep the teaching materials are needed. Based on the findings of this research, it is found that the opinions of ES teachers about the LC of ecological aspects based on the level of complexity are presented in Table 1 below.

The research was conducted by involving 156 ES teachers as respondents who completed an instrument in the form of a questionnaire containing details of subaspects and indicators that exist in the ecological aspect. In this study, the ecological aspect is divided into 10 sub-aspects, namely: (1) the characteristic of the biome; (2) the characteristics of the ecosystem; (3) the characteristics of the ecosystem community; (4) the characteristics of the population that makes up the ecosystem community; (5) the characteristics of functions that occur in the ecosystem; (6) the interspecific interactions between populations; (7) the intraspecific interactions between individuals of a population; (8) the function of biotic components in the ecosystem; (9) the functions of the abiotic component in the ecosystem; and (10) the interaction between biotic and abiotic components in the ecosystem. Based on analysis results, the modes obtained from the ES teacher's opinions about the level of complexity of ecological aspects are as follows. 
Table 1. Modes of Complexity Level of Ecological Aspects according to the Opinion of Elementary School Teachers

\begin{tabular}{|c|c|c|c|}
\hline \multirow{2}{*}{$\begin{array}{l}\text { Level of } \\
\text { Complexity }\end{array}$} & \multirow{2}{*}{ Ecological Acpects } & \multicolumn{2}{|c|}{$\begin{array}{l}\text { Teacher's Opinion } \\
(\mathrm{N}=156)\end{array}$} \\
\hline & & Modus (\%) & $\begin{array}{l}\text { Grade/ } \\
\text { Class }\end{array}$ \\
\hline $\begin{array}{c}\text { Level } 1 \\
\text { (very simple) }\end{array}$ & - & - & - \\
\hline \multirow{3}{*}{$\begin{array}{l}\text { Level } 2 \\
\text { (simple) }\end{array}$} & (5) The characteristics of functions that occur in the ecosystem & $43-50 \%$ & ESa/V \\
\hline & (6) The interspecific interactions between populations & $45 \%$ & $E S$ / V \\
\hline & (8) The function of biotic components in the ecosystem & $41-45 \%$ & ESa/V \\
\hline \multirow{10}{*}{$\begin{array}{c}\text { Level } 3 \\
\text { (rather } \\
\text { complex) }\end{array}$} & (1) The characteristic of biome & $30-37 \%$ & $\mathrm{ES}^{\mathrm{a}} / \mathrm{V}$ \\
\hline & (2) The characteristics of the ecosystem & $36-48 \%$ & $E S^{a} / V$ \\
\hline & (3) The characteristics of the ecosystem community & $46-54 \%$ & $E S^{a} / V$ \\
\hline & $\begin{array}{l}\text { (4) The characteristics of the population that make up the } \\
\text { ecosystem community }\end{array}$ & $39-42 \%$ & $\mathrm{ES}^{\mathrm{a}} / \mathrm{V}$ \\
\hline & (5) The characteristics of functions that occur in the ecosystem & $40-56 \%$ & JHS $/ \mathrm{VIII}$ \\
\hline & (6) The interspecific interactions between populations & $46-50 \%$ & JHS $/ \mathrm{VIII}$ \\
\hline & $\begin{array}{l}\text { (7) The intraspecific interactions between individuals of a } \\
\text { population }\end{array}$ & $45-49 \%$ & $\mathrm{JHS} / \mathrm{VIII}$ \\
\hline & (8) The function of biotic components in the ecosystem & $36 \%$ & $\mathrm{ES}^{\mathrm{a}} / \mathrm{VI}$ \\
\hline & (9) The function of the abiotic component in the ecosystem & $41-44 \%$ & $\begin{array}{l}\mathrm{ES} \text { a/VI \& } \\
\mathrm{JHS}^{\mathrm{b}} / \mathrm{VII}\end{array}$ \\
\hline & $\begin{array}{l}\text { (10) The interaction between biotic and abiotic components in } \\
\text { the ecosystem }\end{array}$ & $50-51 \%$ & $\mathrm{ES}$ a/VI \\
\hline $\begin{array}{l}\text { Level } 4 \\
\text { (complex) }\end{array}$ & (8) The function of biotic components in the ecosystem & $36 \%$ & JHS b/VII \\
\hline $\begin{array}{c}\text { Level } 5 \\
\text { (very complex) }\end{array}$ & - & - & - \\
\hline
\end{tabular}

Based on table 1 it can be seen that according to elementary school teachers, the ecological aspects have complexity levels of 2 (simple), 3 (rather complex), and 4 (complex), while for education levels where the ecological aspect can be taught, elementary teachers argue that the ecological aspect can be taught at elementary and junior high school grades. Sub-aspects (1) the characteristic of biome consist of: the characteristic of water biome based on its structure (its arranging components), the characteristic of land biome based on its structure (its arranging components), the growth of water biome and the factors that influence it, the growth of land biome and the factors that influence it, the evolution of water biome and the factors that influence it, the evolution of land biome and the factors that influence it. According to elementary school teachers, sub aspect 1 has a complexity level of 3 (rather complex). Sub-aspects (2) the characteristics of the ecosystem consist of: the characteristic of natural ecosystem and artificial ecosystem, the characteristic of water ecosystem based on its structure (its arranging components), the characteristic of land ecosystem based on its structure (its arranging components), the growth of water ecosystem and the factors that influence it, the growth of land ecosystem and the factors that influence it, the evolution of water ecosystem and the factors that influence it, the evolution of land ecosystem and the factors that influence it. Elementary school teachers think that sub aspect 2 has a complexity level of 3 (rather complex).

Sub-aspects (3) the characteristics of the ecosystem community consist of: the characteristic of water ecosystem community based on its structure (its arranging components), the characteristic of land ecosystem community based on its structure (its arranging components), the growth of water ecosystem community and the factors that influence it, the growth of land ecosystem community and the factors that influence it, the evolution of water ecosystem community and the factors that influence it, the evolution of land ecosystem community and the factors that influence it. According to elementary school teachers, sub-aspect 3 has a complexity level of 3 (rather complex). Sub-aspects (4) the characteristics of 
the population that make up the ecosystem community consist of: the characteristic of the arrangement population of the water ecosystem community, the characteristic of the arrangement population of the land ecosystem community, the growth of the arrangement population of the water ecosystem community and the factors that influence it, the growth of the arrangement population of the land ecosystem community and the factors that influence it, the evolution of the arrangement population of the water ecosystem community and the factors that influence it, the evolution of the arrangement population of the land ecosystem community and the factors that influence it. Elementary school teachers think that sub aspect 4 has a complexity level of 3 (rather complex).

Sub-aspects (5) the characteristics of functions that occur in the ecosystem consist of: energy flow, food chain, food webs, pyramid ecology (pyramid of total number, pyramid of biomass, pyramid of energy), Biogeochemical cycle (water, carbon, nitrogen, phosphore, sulfur, and othe mineral). According to elementary school teachers, sub-aspect 5 has a complexity level of 2 (simple) and 3 (rather complex). Sub-aspects (6) the interspecific interactions between populations consist of: netralism, competition, cooperation, predation, symbiosis (mutualism, commensalism, and parasitism). According to elementary school teachers, sub-aspect 6 has a complexity level of 2 (simple) and 3 (rather complex). Sub-aspects (7) the intraspecific interactions between individuals of a population consist of: netralism, predation, competition, and cooperation. According to elementary school teachers, sub-aspect 7 has a complexity level of 3 (rather complex).

As revealed in this study, the opinions of elementary school teachers have already confirmed the gradation of the complexity for each level of education. This is because in the secondary school the sub-aspects taught have a higher level of complexity than those in the ESs, namely the ecological sub-aspect with a complexity level of 2 (simple) and 3 (rather complex) for ESs, and materials at level 3 (rather complex) and level 4 (complex) for junior high school (JHS) level. Students at the elementary level are still at the basic stage, so that they should be given teaching materials with a simple or not too complicated level of complexity. If an aspect of science consists of a lot of material coverage, its basic knowledge can be taught starting at the elementary grade. Then more complex materials can be taught at the next level of education, namely JHS or senior high school (SHS). If ES children are at the concrete operational stage, students at the junior and senior high school levels are 12-17 years old, so that according to their development stage, these teens are at the formal operational stage where they can think logically, abstractly, and ideally to solve certain problems, including complex things [18].

Based on table 2, it can be seen that according to ES teachers, the ecological aspects can be taught
Sub-aspects (8) the function of biotic components in the ecosystem consist of: functional status (nisia) in the food chain and food webs (produser, consumer, garbage eater, and decoder), functional status in the foot sources (autotroph and heterotroph). Elementary school teachers argue that sub aspect 8 has complexity levels 2 (simple), 3 (rather complex), and 4 (complex). Sub-aspects (9) the function of the abiotic component in the ecosystem consist of: the functions of land components on the ecosystem based on the chemical characteristic, the functions of land components on the ecosystem based on the physical characteristic, the functions of atmospheric components on the ecosystem based on the physical characteristic, the functions of atmospheric components on the ecosystem based on the chemical characteristic, the functions of hydrologic component in the ecosystem. Elementary school teachers argue that sub aspect 9 has a complexity level of 3 (rather complex). Sub-aspects (10) the interaction between biotic and abiotic components in the ecosystem consist of: the interaction between biotic component and edaphic/ land component, the interaction between biotic component and atmospheric/ air, the interaction between biotic component and hydrologic component. According to the elementary school teacher, sub aspect 10 has a complexity level of 3 (rather complex).

Based on the assessment of the level of complexity and class level for each ecological subaspect and the indicators in it, then from the mode obtained, a learning continuum of ecological aspect is compiled based on the level of complexity for elementary to secondary school grade according to the opinion of elementary school teachers, which is presented in table 2 .

starting at the fifth grade of ES, namely the sub-aspects that have a complexity level of 2 (simple) and 3 (rather complex). Sub aspect (1) the characteristic of a biome, (2) the characteristics of the ecosystem community, (3) the characteristics of the ecosystem community, and (4) the characteristics of the population that makes up the ecosystem community can be taught starting at grade $\mathrm{V}$ ES as they have a complexity level of 3 (rather complex). However, this is considered illogical, because sub aspect (1), which is rather complex, would probably inappropriate if taught to ES students who are still at the stage of concrete operational development. The aspect would be appropriate to be taught at grade VII JHS instead. However, sub-aspect (2), (3), and (4) specifically indicator the characteristic of the ecosystem, the characteristic of the ecosystem community, and the characteristic of the population that makes up the ecosystem community based on its structure can begin to be taught at $\mathrm{V}$ grade of elementary school, because the indicators are simple. Meanwhile, the growth and the evolution of the ecosystem, the growth and evolution of the ecosystem community, and the growth and evolution of the population that makes up the ecosystem community and factors that influence it are rather complex (level 3), so they should be taught at 
grade VII JHS. This is in line with what Mendala found in 2019 [9], that the characteristics of the biome, the growth and evolution indicators in the sub-aspect the characteristics of the ecosystem, the characteristics of the ecosystem community, and the characteristics of the population that makes up the ecosystem community, according to the opinion of Biology education expert, are logical if taught at grade VII JHS.

Sub-aspect (5) the characteristics of functions that occur in the ecosystem with a complexity level of 2 (simple) can be taught starting at grade V ES, then continued at grade VIII JHS, for those with a complexity level of 3 (rather complex). The indicators in sub-aspect 5 consist of simple to rather complex materials. Teachers argues that the food chain, the food web. energy flow, pyramid, and water cycle can be taught in elementary school, while other biogechemical cycles (carbo, nitrogen, phosphorus cycle etc.) can be taught in junior high school. There are logical and illogic opinions when compared with expert opinions in previous studies. According to experts, energy flow, food chains, food webs, all of which are simple materials that can be taught at ESs. Pyramid of ecology (pyramid of the total number, pyramid of biomass, and pyramid of energy) is a rather complex material, so it could be taught at JHS, while the biogeochemical cycle (water, carbon, nitrogen, phosphor, sulfur, and other minerals) is considered complex, so it should be taught at grade X SHS. Students at the junior and senior high school levels are both at the stage of formal operational development, but students at SHS are considered more mature cognitive development, so they can learn materials with a higher level of complexity than do JHS students.

Table 2. Learning Continuum of Ecological Aspect based on the level of complexity according to the opinion of elementary school teachers

\begin{tabular}{|c|c|c|}
\hline Class & $\begin{array}{l}\text { Complexity } \\
\text { Level }\end{array}$ & Ecological Sub-aspect \\
\hline \multirow[t]{7}{*}{ V } & $3^{c}$ & $\begin{array}{l}\text { (1) The characteristic of biome: the characteristics, growth, and evolution of land and water biomes } \\
\text { based on their structure. }\end{array}$ \\
\hline & $3^{c}$ & $\begin{array}{l}\text { (2) The characteristics of the ecosystem: the characteristics of natural and artificial ecosystems, the } \\
\text { characteristics, growth and evolution of the land and water ecosystems based on their structure. }\end{array}$ \\
\hline & $3^{c}$ & $\begin{array}{l}\text { (3) The characteristics of the ecosystem community: the characteristics, growth and evolution of the } \\
\text { land and water ecosystems community based on their structure. }\end{array}$ \\
\hline & $3^{c}$ & $\begin{array}{l}\text { (4) The characteristics of the population that make up the ecosystem community: the characteristics, } \\
\text { growth and evolution of population that make up the land and water ecosystems community } \\
\text { based on their structure. }\end{array}$ \\
\hline & $2^{\mathrm{b}}$ & $\begin{array}{l}\text { (5) The characteristics of functions that occur in the ecosystem: food chains, food webs, energy } \\
\text { flows, pyramids, water cycles. } \\
\text { (Continued in grade } 8 \text { th/ 3c) }\end{array}$ \\
\hline & $2^{\mathrm{b}}$ & $\begin{array}{l}\text { (6) The interspecific interactions between populations: mutualism, parasitism, commensalism } \\
\text { symbiosis. } \\
\text { (Continued in grade } 8 \mathrm{th} / 3 \mathrm{c} \text { ) }\end{array}$ \\
\hline & $2^{\mathrm{b}}$ & $\begin{array}{l}\text { (8) The function of biotic components in the ecosystem: the functional status (nisea) in food chains } \\
\text { and webs, consists of producers, consumers, and decomposers. } \\
\text { (Continued in grade } 6 \text { th/ } 3 \mathrm{c} \text { and } 7 \text { th/ } 4 \mathrm{~d} \text { ) }\end{array}$ \\
\hline \multirow[t]{3}{*}{ VI } & $3^{c}$ & $\begin{array}{l}\text { (8) The function of biotic components in the ecosystem: Functional status in food sources } \\
\text { (Autotrophs \& heterotrophs). }\end{array}$ \\
\hline & $3^{c}$ & $\begin{array}{l}\text { (9) The function of the abiotic component in the ecosystem: The function of land in ecosystems is } \\
\text { based on physical and chemical properties. } \\
\text { (Continued in grade } 7 \mathrm{th} / 3 \mathrm{c} \text { ) }\end{array}$ \\
\hline & $3^{c}$ & $\begin{array}{l}\text { (10) The interaction between biotic and abiotic components in the ecosystem: the interaction of biotic } \\
\text { components with edaphic components / soil, atmosphere / air, and hydrological components. }\end{array}$ \\
\hline \multirow[t]{2}{*}{ VII } & $3^{c}$ & $\begin{array}{l}\text { (9) The function of the abiotic component in the ecosystem: the function of the atmospheric } \\
\text { components in the ecosystem based on physical and chemical properties, the function of the } \\
\text { hydrologic components in the ecosystem. }\end{array}$ \\
\hline & $4^{\mathrm{d}}$ & $\begin{array}{l}\text { (8) The function of biotic components in the ecosystem: functional status in food sources (autotrophs } \\
\text { \& heterotrophs). }\end{array}$ \\
\hline \multirow[t]{3}{*}{ VIII } & $3^{c}$ & $\begin{array}{l}\text { (5) The characteristics of functions that occur in the ecosystem: carbo, nitrogen, phosphorus, sulfur, } \\
\text { other minerals cycle. }\end{array}$ \\
\hline & $3^{c}$ & $\begin{array}{l}\text { (6) The interspecific interactions between populations: neutralism, predation, competition, } \\
\text { cooperation. }\end{array}$ \\
\hline & $3^{c}$ & $\begin{array}{l}\text { (7) The intraspecific interactions between individuals of a population: neutralism, predation, } \\
\text { competition, cooperation. }\end{array}$ \\
\hline \multicolumn{3}{|c|}{ a : very simple } \\
\hline
\end{tabular}


Besides, sub-aspect (6) the interspecific interactions between populations with a complexity level of 2 (simple) can begin to be taught in $\mathrm{V}$ grade of ES, then continued in grade VIII JHS for those with a complexity level of 3 (rather complex). Sub-aspect 6 consists of simple to rather complex materials, so it can be taught starting at ES and being continued at the next grade. Symbiosis (mutualism, commensalism, and parasitism) is a simple indicator, so that it can be taught starting at the ES grades, while neutralism, competition, cooperation, predation are rather complex and can be taught starting at the JHS grade. Sub aspect (7) the intraspecific interactions between individuals of a population have complexity level 3 (rather complex) and can be tought at VIII JHS. Sub-aspect (8), the functions of biotic components in the ecosystem, at level 2 (simple) can be taught starting at grade V ES, then continued at grade VI ES with materials at level 3 (rather complex) and grade VII JHS with level 4 or complex ones. As the material in sub-aspect 8 consist of simple to complex material, it can be taught at the ES grade for discussions on producers, consumers, garbage eater, and decoder. The more complex material, namely functional status in the food sources (autotroph and heterotroph) can be taught at VI grade with complexity level 3 (rather complex) and at JHS with complexity level 4 (complex).

Sub-aspect (10), the interaction between biotic and abiotic components in the ecosystem, at level 3 (rather complex) can be taught in grade VI ES. This is considered logical because this sub-aspect is not too complicated. Sub-aspect (9), the function of the abiotic component in the ecosystem, with a complexity level of 3 (rather complex) can be taught starting at grade VI ES, then continued at grade VII JHS also with level 3 (rather complex) materials. If one indicator is taught repeatedly at different levels with the same level of complexity, it is possible that this opinion follows the rules of the spiral curriculum. The continuity of the curriculum in the curriculum organization needs to be considered, especially with regard to the substance of the material being studied by learners, so that there should be no repetitions or jumps with unclear difficulty levels. The spiral approach is an attempt to apply this factor. This means that the material that students learn is getting deeper and deeper based on vertical and horizontal breadth [19].

When viewed from the opinions of 156 ES teachers who were respondents in this study, the mode obtained is not too high because the respondents have quite diverse opinions. This is understandable because ES teachers do not specifically study biology in depth. However, researchers consider it important to reveal their opinions because LC starts from basic education, so teachers at the ES level also have an important role. Since at the elementary level students are taught with various basic materials, they will be ready to study at a higher level of education, namely JHS and SHS. ES teachers are also considered to understand how the abilities of ES students are, so that their opinions can be used as one of the considerations in the curriculum development, especially regarding the material presented to students at the ES grades and related to basic knowledge of the ecological aspect.

In an ideal curriculum, the level of competence and pedagogic material taught by a teacher must be in accordance with the aspects of learning material and student development [20], [21]. Curriculum development has to show the relationship between subject matter required in the further learning process for higher levels of education, and these things should actually be taught at an earlier stage. In addition, learning materials taught at lower levels of education do not have to be taught again at the next level, so as to avoid overlaps of material arrangements in the teaching and learning process. In addition, standards that pay attention to the essence of LC are also needed in developing a curriculum [22], [23].

The development of LC must pay attention to the aspects of cognitive abilities targeted starting from the simplest to the most complex aspects [24]. Furthermore, what needs to be considered is the complexity of the teaching materials. It depends on the breadth and depth of an aspect of science selected as the material and as a tool to master the targeted competencies. The benefits of LC in the learning process include that it can be used (1) as a basis for choosing teaching materials and learning resources that are in accordance with the education level of students, (2) by teachers to develop individual learning and lesson planning at the next level, and (3) as one of the foundations for compiling, developing, and improving the curriculum [25],[26].

\section{CONCLUSION}

Based on the research results that have been described previously, it can be concluded that elementary school teachers think that ecological aspect can be taught at V and VI of elementary school grade for sub aspects that have complexity levels 2 (simple) and 3 (rather complex), and continue at VII and VIII of junior high school grade for ecological sub-aspects that have complexity level 3 (rather complex) and 4 (complex). According to the elementary school teacher, sub aspects (1) the characteristic of biome, (2) the characteristics of the ecosystem community, (3) the characteristics of the ecosystem community, (4) the characteristics of the population that make up the ecosystem community, (5) the characteristics of functions that occur in the ecosystem, (6) the interspecific interactions between populations, (8) the 
function of biotic components in the ecosystem, (9) the function of the abiotic component in the ecosystem, and (10) the interaction between biotic and abiotic components in the ecosystem can begin to be taught at the elementary school grade, but there are several subaspects where some of the indicators are continued at junior high school grade with higher complexity level. At the junior high school grade, elementary school teachers argue that the sub-aspects that can be taught are sub-aspects (7) the intraspecific interactions between individuals of a population, and continued material from sub aspects (5) the characteristics of functions that occur in the ecosystem, (6) the interspecific interactions between populations, (8) the function of biotic components in the ecosystem, and (9) the function of the abiotic component in the ecosystem. There are logic and illogic opinions when compared with the opinion of Biology experts from previous research. The learning continuum should show the gradation from a simple level to a more complex level at each grade of education.

\section{AUTHORS’ CONTRIBUTIONS}

Author contributions are in the proses of developing instruments, collecting and analyzing data, and reporting the results of research.

\section{ACKNOWLEDGMENTS}

The researchers give thanks to the Ministry of Research, Technology and Higher Education who helped this research.

\section{REFERENCES}

[1] Y. Prihatni, Kumaidi, \& Mundilarto, Pengembangan Instrumen Diagnostik Kognitif pada Mata Pelajaran IPA di SMP, Jurnal Penelitian dan Evaluasi Pendidikan, 20(1), 2016, pp 111-125.

[2] D. T. Dodge , C. Heroman, J. Charles, \& J. Maiorca, Beyond Outcomes: How Onging Assessment Supports Children's Learning and Lead to Meaningful Curriculum, YC Young Children, 59(1), 2004, pp 20-28.

[3] R. Pramana Situmorang, Analisis Learning Continuum Tingkat SD sampai SMP pada Tema Sistem Pencernaan Manusia, Scholaria, 6(2), 2016.

[4] S. Suyanto \& Y. Wibowo, Curriculum review of teacher professional development program based on Biology teacher profile in technological pedagogical and conten knowledge, 2017. https://iopscience.iop.org/article/10.1088/17426596/1097/1/012042/pdf
[5] H. Baharun, Pengembangan Kurikulum Teori dan Praktik, Pustaka Nurja, Yogyakarta, 2018.

[6] B. Subali, Kumaidi, \& N. Siti Aminah, Developing A Scientific Learning Continuum of Natural Science Subjects at Grades 1-4, Journal of Turkish Science Education, 15(2), 2018, pp 66-81. http://doi.org/10.12973/tused.10231a

[7] E. Juniati \& B. Subali, Teacher's Opinion about Learning Continuum of Genetics based on Student's Level on Competence, Published bt the: American Institute of Physics. In AIP Conference Proceedings, 2017.

[8] I. G. A. T. Agustiana, Konsep dasar IPA Aspek Biologi,Ombak, Yogyakarta, 2014.

[9] Mendala, B. Subali, \& Paidi, Developing A Learning Continuum on Ecological Aspect from Elementary to Senior High School Based on The Opinions of Biology Education Experts, Journal of Physics: Conference Series. IOP Publishing, 2019.

[10] M. Utami Kusumawati, B. Subali, \& Paidi, Developing A Learning Continuum of Biological Resources Management Aspect from Elementary School to Senior High School Based on The Experts' Opinions, Journal of Physics: Conference Series. IOP Publishing, 2019.

[11] W. W. Daniel, Statistik Non Parametrik Terapan, Gramedia, Jakarta, 1989.

[12] S. Bucler \& P. Castle, Psychology of Teachers, Sage Publication, London, 2014.

[13] J W. Santrock, Educational Psicology $5^{\text {th }}$ edition, Asia: McGraw-Hill Education, 2014.

[14] F. Ibda, Perkembangan Kognitif: Teori Jean Piaget, Intelektualita, 3(1), 2015, pp 27-38.

[15] D. Febrini, Psikologi Pembelajaran, Yogyakarta: Pustaka Pelajar, 2017

[16] D. H. Schunk, Learning Theories $6^{\text {th }}$ edition, Pearson Education Inc, Boston, 2012.

[17] M. S. Knowles, The Modern Practice of Adult Education from Pedagogy to Andragogy, New York: Cambridge The Adult Education Company, 1997.

[18] Desmita, Psikologi Perkembangan. Remaja Rosdakarya, Bandung, 2009.

[19] A. Sugiana, Proses Pengembangan Organisasi Kurikulum dalam Meningkatkan Pendidikan Di 
Indonesia, Jurnal Pedagogik, 05(02), 1997, pp 257273.

[20] S. F. Shawer, Theacher-Driven Curriculum Development at the Classroom Level: Implications for Curriculum, Pedagogy and Teacher Trainging, Journal Teacher Education, 63, 2017, pp 296-313.

[21] Q. Lu \& E. Liu, Aligment between High School Biology Curriculum Standard and the Standardised test of four provinces in China, Journal Biological Education , 46, 2012, pp 149-64.

[22] A. Idi, Pengembangan Kurikulum Teori \& Praktik, Rajawali Press, Yogyakarta, 2007.

[23] S. Suyanto, The Implementation of The Scientific Approach though $5 \mathrm{Ms}$ of The New Curriculum 2013 in Indonesia, Jurnal Cakrawala Pendidikan No. 1, 2018, pp 22-29.

[24] Sugihartono, K N. Fathiyah, F. A. Setiawati, F . Harahap, \& S. R. Nurhayati, Psikologi Pendidikan, UNY Press, Yogyakarta, 2007.

[25] NWEA (North West Evaluation Association), Primary Use of the Learning Continuum. Idaho State University, Pocatello, 2003.

[26] Department of Education and Communities, An Overview of The Literacy Continuum K-10, State of New South Wales, Sydney, 2013. 